\title{
Improving Drought Tolerance in White Maize Population
}

\author{
El-Shamarka S.A. ${ }^{1}$; Darwish I.H. ${ }^{1}$; Marwa M.El-Nahas ${ }^{1}$; Gamea H.A. ${ }^{2}$ \\ and El-Harany A.A. ${ }^{1}$ \\ ${ }^{1}$ Crop Science Dept., Faculty of Agriculture, Menoufia Univ., Egypt \\ ${ }^{2}$ Maize Research Section, Field Crops Research Institute, ARC, Egypt
}

\begin{abstract}
Field experiments were carried out in four successive seasons (2015 to 2018) at the experimental farm of faculty of agriculture, Menoufia University, in Shebin El-Kom, Egypt. The main objectives of this study were to study the effect of water stress on different maize traits and identify the effectiveness of $S_{1}$ recurrent selection for improving drought tolerance in Tep\#5 population (white). $100 \mathrm{~S}_{1}$ 's were isolated and evaluated under normal irrigation (NI) and drought stress (DS) at flowering stage. The highest yielding 10 lines $(10 \%)$ selected under each environment were random mated by bulking pollen and make crosses handly. Two sub-populations were obtained (Tep\#5-NI and Tep\#5-DS).The population (Tep\#5-NI) along with the original population (Tep\#5) were evaluated for 19 traits under normal irrigation condition (NI) and the population (Tep\#5-DS) along with the original population (Tep\#5) were evaluated under drought stress condition (DS) in a randomized complete block design with four replications. Results indicated wide genetic variation among $\mathrm{S}_{1}$ progenies for most studied traits under both selection environments (NI and DS). Heritability estimates were generally higher under drought stress than under normal irrigation conditions. Number of kernels/row, 100-kernels weight and ear length traits were predicted to grain yield more efficiently under drought stress than under normal irrigation conditions. One cycle of $S_{1}$ recurrent selection under water-stress caused a significant actual improvement of grain yield of the newly developed population (Tep\#5-DS) over its original population (Tep\#5) of $15.47 \%$. The improved population Tep\#5-NI developed by using normal irrigation as a selection environment showed significant actual improvements in grain yield under normal irrigation (12.46\%) environment. Selection under water stressed and non-stressed irrigations were efficient in improving grain yield.
\end{abstract}

Key words: Maize, Populations, Recurrent selection, Drought tolerance, physiological characters, yield and its components.

\section{INTRODUCTION}

Maize (Zea mays L.) is the third most important cereals after wheat and rice all over the world as well as in Egypt. In Egypt, the cultivated area of maize reached 2.619 million fad with total yield and annual average production 7.10 million tones and 2.711 ton/fad, respectively (FAOSTAT, 2017). Irrigation is a major limiting factor affecting plant growth, development and yield mainly in arid and semiarid regions where plants are often exposed to periods of water stress (drought stress).

Drought is a major reason for yield loss worldwide, reducing average yields about $50 \%$ and more (Wang et al.2003; Cairns et al. (2013) and Rekaby et al. (2017). Breeding for drought tolerance in maize is a complex task, because, drought might affect the crop at any stage of development. Many breeders have focused emphasizing the effects of drought at flowering and grain filling, because, maize is most sensitive at these stages (Maazou et al., 2016). It is well established that drought stress impairs numerous metabolic and physiological processes in plants (Efeoğlu et al., 2009). The reaction of the plants to drought differs significantly at various organizational levels depending upon intensity and duration of stress, as well as, plant species and the stage of development (Chaves et al., 2003).
One of the goals of the Egyptian breeders is breeding hybrids ifhigh yield under normal and stress environmental conditions, such as, drought and limited irrigation water to expand cultivation in the new lands. This might reduce the importation bill and rationalize irrigation water under limited Egyptian water resources.

Recurrent selection is population improvement that increase the frequency of favorable alleles while maintenance genetic variation (Doerksen, 2003). The $S_{1}$ recurrent selection also called endogamic selection, involves repeated regeneration of the first selfed $\left(S_{1}\right)$ progenies and subsequent evaluation of the progenies to select the superior ones that can be recommended to reconstitute improved version of the parent variety. In maize, this selection scheme is considered more efficient than other selection schemes in improving broad-based populations as it conserves that, deleterious homozygous genes eliminated through selection (Leta and Jifar, 2010). $\mathrm{S}_{1}$ recurrent selection proved to be effective in improving drought tolerance in maize (Al-Naggar et al., 2004).

The main objectives of this recent study were to study the effect of water stress on different maize traits and identify the effectiveness of $S_{1}$ recurrent selection for improving drought tolerance in the two maize populations. 


\section{MATERIALS AND METHODS}

This study was carried-out in four successive summer seasons (2015 to 2018) at the experimental farm of the faculty of agriculture, Menoufia University, (Shebin El-Kom, Egypt). The Tep\#5 population (white) was used as a base population to practice one cycle of $S_{1}$ recurrent selection for drought tolerance.

\section{Experimental site}

The field experiments were conducted in northern Egypt (Shebin El-Kom)..Soil samples were taken before sowing until $40 \mathrm{~cm}$ depth to determine some physical and chemical properties of soil according to Jackson (1973) and Black (1982). The experimental site, classified as clay loam soil. Some physical and chemical properties of soil located in the experimental site are shown in (Table $1 \mathrm{a}$ and $\mathrm{b}$ ), respectively.

2. Experimental procedure and cultural practices:

\subsection{Formation of $S_{1}$ lines}

In the 2015 season, kernels of the openpollinated population Tep\#5 (white) was sown at Shebin El-Kom, on the $5^{\text {th }}$ of May under normal irrigation condition (NI). More than two hundred vigorous and disease-free plants were chosen before silking, and was self-pollinated. At harvest, the best 100 selfed $\left(S_{1}\right)$ ears were selected based on their ear characteristics and grain yield weight. Ears of $\mathrm{S}_{1}$ 's were divided to two parts, the first were assigned for evaluation in the next season and the second parts were kept as remnant $S_{1}$ 's for developing the new cycle of the population.

2.2. Evaluation of the $S_{1}$ lines and Random Mating of the $S_{1}$ Lines

In 2016 season, seeds of $100 \mathrm{~S}_{1}$ lines that were selected was sown at Shebin El-Kom farm in the $1^{\text {st }}$, May in single-ridge/plots of $2.5 \mathrm{~m}$ long and $0.7 \mathrm{~m}$ width for evaluation under two irrigation regimes:

1- Normal conditions (NI): seven irrigations were applied, the first one was applied at 21 days often sowing (DAS) and other irrigations were repeated every 12 days.

2- Drought stress (DS): five irrigations were applied, the first one was applied at 21 DAS and other irrigations were repeated every 12 days, but withholding the $3^{\text {th }}$ (45 DAS) and $5^{\text {th }}(69$ DAS $)$ irrigations.

A randomized complete block (RCBD) design with three replications was used for evaluating each group of $\mathrm{S}_{1}$ lines for grain yield characters. Experiment of drought stress was surrounded with a wide ridge $(2.1 \mathrm{~m}$ width) to avoid water leak between treatments. Two kernels were sown per hill at $25 \mathrm{~cm}$ spacing. Plants were thinned after seedling emergence to secure one plant per hill to produce 24000 plants per fad. All other agricultural practices were done according to the recommendation of ARC, Egypt. Harvesting was done after 110 days. At harvest, the highest $10 \mathrm{~S}_{1}$ 's (about 10\%) were selected under normal irrigation and drought stress. Selection of $\mathrm{S}_{1}$ 's based mainly on grain yield per plot and short anthesis-silking interval (ASI) a secondary selection criteria. Finally, two groups of $\mathrm{S}_{1}$ 's (under normal (NI) and drought stress (DS) conditions) namely, Tep\#5-NI and Tep\#5-DS.

\subsection{Intercrossing fields}

In the summer season of 2017 , the ten selected $\mathrm{S}_{1}$ lines from each group were planted in Shebin ElKom, at $1^{\text {st }}$ May in ten ridges contains 25 hills/ ridge. These $\mathrm{S}_{1}$ lines were randomly mated by bulking pollen from the $S_{1}$ plants and using hand crossing. This procedure was applied separately each group. At harvest, ears were shelled, dried and bulked for each group to form seeds of the two sub-populations as follows: (1) Sub-population I (Tep\#5-NI) and (2) Sub-population II (Tep\#5-DS).

\subsection{Evaluation experiments}

In the summer season of 2018 ( $1^{\text {st }}$ May) were evaluated the two new sub-populations that produced from intercrossing along with original populations (Tep\#5) at Shebin El-Kom in two separate experiments represented irrigation regimes, i.e.; normal irrigation and drought-stress at flowering stage. The two trials were arranged in a Randomized Complete Block Design (RCBD) with four replications. Each plot consisted of 5 ridges, 5 $\mathrm{m}$ long and $0.7 \mathrm{~m}$ width (plot area was $17.5 \mathrm{~m}^{2}$ ), with plants spaced $25 \mathrm{~cm}$ apart within ridges.

Table 1a: Physical properties of the experimental field soil (Over years)

\begin{tabular}{|c|c|c|c|c|c|c|c|}
\hline \multirow{2}{*}{$\begin{array}{l}\text { Soil Depth } \\
(\mathrm{cm})\end{array}$} & \multicolumn{3}{|c|}{$\begin{array}{c}\text { Particles Size Distribution } \\
(\%)\end{array}$} & \multirow{2}{*}{$\begin{array}{c}\text { Bulk } \\
\text { Density } \\
\left(\mathrm{gm} \mathrm{cm}^{-3}\right)\end{array}$} & \multirow{2}{*}{$\begin{array}{c}\text { Field } \\
\text { Capacity } \\
(\%)\end{array}$} & \multirow{2}{*}{$\begin{array}{c}\text { Permanent } \\
\text { Wilting Point } \\
(\%)\end{array}$} & \multirow{2}{*}{$\begin{array}{c}\text { Available } \\
\text { Water } \\
(\%)\end{array}$} \\
\hline & Sand & Silt & Clos & & & & \\
\hline $0-40$ & 21.40 & 30.66 & 47.94 & 1.20 & 34.1 & 17.73 & 16.37 \\
\hline
\end{tabular}

Table 1b: Chemical properties of the experimental field soil (Over years)

\begin{tabular}{|c|c|c|c|c|c|c|c|c|c|c|}
\hline \multirow{2}{*}{$\begin{array}{l}\text { Soil Depth } \\
\text { (Cm) }\end{array}$} & \multirow[t]{2}{*}{$\mathbf{p H}$} & \multirow{2}{*}{ 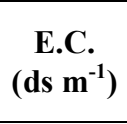 } & \multirow{2}{*}{$\begin{array}{c}\text { O. M. } \\
(\%)\end{array}$} & \multicolumn{4}{|c|}{$\begin{array}{l}\text { Soluble cations } \\
\left(\mathrm{meg} \mathrm{l}^{-1}\right)\end{array}$} & \multicolumn{3}{|c|}{$\begin{array}{l}\text { Soluble anions } \\
\left(\mathrm{meg} \mathrm{l}^{-1}\right)\end{array}$} \\
\hline & & & & $\mathrm{Na}^{+}$ & $\mathbf{K}^{+}$ & $\mathrm{Ca}^{+2}$ & $\mathrm{Mg}^{+2}$ & $\mathrm{Cl}^{-}$ & $\mathrm{HCo3}^{-2}$ & $\mathrm{So}^{-2}$ \\
\hline $0-40$ & 8.67 & 0.30 & 1.8 & 3.3 & 0.07 & 0.25 & 0.15 & 1.1 & 1.55 & 1.12 \\
\hline
\end{tabular}


Plants were thinned to one per hill before the first irrigation, to produce 24000 plants per fad. Other agricultural practices were done according to the recommendation of ARC, Egypt.

\section{Studied characters:}

\section{1- Agronomic characters}

Days to $50 \%$ anthesis (DTA, days), days to 50 $\%$ silking (DTS, days), anthesis-silking interval (ASI, days), plant height $(\mathrm{PH}, \mathrm{cm})$ and ear height $(\mathrm{EH}, \mathrm{cm})$.

\section{2- Water relations}

Samples were taken after 75 days from sowing, to determine each of the following water relations:

1. Relative water content (RWC, \%): determined by the method of Barrs and Weatherley (1962) as follows:

$$
\text { RWC } \%=\frac{\text { Freshwt }- \text { Dry wt }}{\text { Turgid wt }- \text { Dry wt. }} \times 100
$$

Full turgid weight were recorded after soaking leaves in distilled water for 6 hours under laboratory light and temperature condition. Leaves dried at $70^{\circ} \mathrm{C}$ for 72 hours to determine dry weights.

2. Osmotic pressure (OP, bar): The cell sap of leaves was used for measuring the TSS by the refractometer, then special tables were used to calculate the osmotic pressure as described by Gosev (1960).

3. Transpiration rate (TR, mg/gfw.hr): The transpirational lose water was determined using the weight method as described by Kreeb (1990).

\section{3- Physio-chemical constituents}

Samples were taken after 75 days from sowing,

to determine each of the physio-chemical constituents as follows:

1. Enzymes activities; Fresh leaves were used to determine the activity of peroxidase and phenoloxidase enzymes using spectrophotometer (CT-2200 Spectrophotometer- Medline, Scientific limited). Peroxidase activity (O.D. /g F.W.) was expressed as changes in absorbance per minute per gram fresh weight (Reuveni et al., 1992). The increase in absorbance density at $470 \mathrm{~nm}$ was recorded. Activity of phenoloxidase (O.D. /g F.W.) was expressed as the change in the absorbance of the mixture at $495 \mathrm{~nm}$ (Matta and Dimond, 1963).

2. Photosynthetic pigments (SPAD): Ear leave samples of five plants were randomly taken at 65 DAS to determine the total chlorophyll $($ Chl. $\mathrm{a}+\mathrm{b})$ using SPAD meter.

3. Proline content (PC, $\boldsymbol{\mu g} / \mathbf{g}$ D.W.): It was determined in leaves at 65 DAS according to the method described by Bates et al. (1973).
3.4- Yield and its components:

At harvest, the following data were recorded: Number of ears / plant (EPP), ear diameter $(\mathrm{ED}, \mathrm{cm})$, ear length $(\mathrm{EL}, \mathrm{cm})$, number of rows / ear (RPE), number of kernels / row (KPR), 100-kernels weight (100 KW, g), kernels weight / ear (KWPE, g), grain yield /plot (GYPP, kg) and grain yield (GY, ton/fad).

\section{5- Grain quality}

1. Protein percentage (PP, \%): Protein percentage in the dry kernels was calculated by multiplying $\mathrm{N} \%$ by the factor of 5.75 . Nitrogen $\%$ was determined using micro Kjeldahel method as outlined by AACC (2000).

2. Protein yield (PY, kg /fad): It was determined by multiplying kernel yield/fad by kernel protein percentage.

3.6- Genetical parameters

1. Genotypic $\left(\sigma_{g}^{2}\right)$ and phenotypic $\left(\sigma_{p}^{2}\right)$ variances

Analysis of variance and expected mean squares (E.M.S) of RCBD under different environments.

\begin{tabular}{lccc}
\hline S.O.V & Df & MS & EMS \\
\hline Replications & $\mathrm{r}-1$ & - & - \\
Genotypes & $\mathrm{g}-1$ & $\mathrm{M}_{2}$ & $\sigma^{2}{ }_{\mathrm{e}}+\mathrm{r} \sigma_{\mathrm{g}}^{2}$ \\
Error & $(\mathrm{r}-1)(\mathrm{g}-1)$ & $\mathrm{M}_{1}$ & $\sigma_{\mathrm{e}}^{2}$ \\
\hline
\end{tabular}

Genotypic $\left(\sigma_{g}^{2}\right)$ and phenotypic $\left(\sigma_{p}^{2}\right)$ variances were computed as follows:

$\sigma_{\mathrm{E}}^{2}=\frac{\mathrm{M}_{2}-\mathrm{M}_{1}}{\mathrm{r}}$
$\sigma_{\mathrm{P}}^{2}=\sigma_{\mathrm{E}}^{2}+\frac{\sigma_{\mathrm{e}}^{2}}{\mathrm{~F}}$

Where $r=$ number of replications.

\section{Heritability}

Heritability $(\%)$ in the broad sense $\left(\mathrm{h}_{\mathrm{b}}^{2}\right)$ for a different environments was estimated according to Hallauer and Miranda (1988) by using the following formula:

$\mathrm{h}_{\mathrm{b},}^{2}, \mathrm{~h}=\frac{\sigma_{\mathrm{g}}^{2}}{\sigma_{\mathrm{p}}^{2}} \times 100$

\section{Correlations}

Genotypic $\left(r_{\mathrm{g}}\right)$ correlations were calculate between each pair of studied traits under each environment according to Betran (1999) using the following formulae:

$$
\mathrm{r}_{\mathrm{g}}=\frac{\sigma_{\mathrm{gxy}}^{22}}{\left(\sigma^{2} \mathrm{gx}^{\mathrm{x} \sigma^{2}}\right)^{\frac{1}{2}}} \mathrm{X} 100
$$

Where: $\sigma_{\text {gxy }}^{2}=$ the phenotypic and genotypic covariance of the two traits, $X$ and $Y$, respectively.

$\sigma^{2}$ axd $\sigma^{2}$ gy $=$ the genotypic variance of the two traits, $x$ and $y$, respectively.

\section{5- Statistical analysis}

Analysis of variance was computed according to Snedecor and Cochran (1989). LSD test was used to compare the differences between means. 


\section{RESULTS AND DISCUSSION}

Experiment I: Evaluation of $100 S_{1}$ progenies of the white population (Tep\#5) for drought tolerance.

a. Analysis of variance:

The analyses of variance for all studied traits of $\mathrm{S}_{1}$ progenies (derived from Tep\#5 population) evaluated under normal and drought stress conditions were presented in Table (2). Results of the analysis of variance revealed significant or highly significant differences among genotypes $\left(S_{1}\right.$ progenies) for all studied traits under both normal and drought stress conditions. These differences of $\mathrm{S}_{1}$ plants allowed the possibilities of culling by selection to normal and drought conditions.

The measured characters for evaluated $\mathrm{S}_{1}$ lines under normal irrigation were less uniform than the corresponding measurements under water-stress condition, except for, grain yield per plot, that was classified by the magnitude of recorded coefficient of variations (C.V.). In this concern, Umar et al. (2015) reported larger (C.V.) were for days to $50 \%$ anthesis, days to $50 \%$ silking, anthesis-silking interval and grain yield under water stress compared to non-stress conditions.

\section{b.Performance of $S_{1}$ progenies}

Values of grain yield/plot of the $100 \mathrm{~S}_{1}$ progenies ranged from 1.45 to $2.61 \mathrm{~kg} / \mathrm{plot}$ under normal condition, and from 0.35 to $1.18 \mathrm{~kg} / \mathrm{plot}$ under drought stress condition, with mean values of 1.72 and $0.69 \mathrm{~kg} / \mathrm{plot}$, respectively (Table 3). A reduction of $60.05 \%$ in grain yield /plot of the 100 $\mathrm{S}_{1}$ progenies due to drought stress was accompanied by a significant reduction in ear length $(17.51 \%)$, number of kernels /row (19.67\%) and 100-kernels weight $(7.63 \%)$. As for yield component, number of kernels /row showed maximum reduction due to drought stress, while minimum reduction was observed for number of rows /ear. On the other hand, drought stress caused an increases days to 50 $\%$ anthesis $(3.16 \%)$, days to $50 \%$ silking $(5.92 \%)$ and anthesis-silking interval $(88.46 \%)$. Reductions in means of the $100 \mathrm{~S}_{1}$ progenies due to water stress was also accompanied by reductions in ranges (more uniform) for traits; grains yield /plot, 100-kernels weight, number of kernels /row, number of rows /ear, ear diameter and ear length. Moreover, increases in means of the $100 \mathrm{~S}_{1}$ 's due to drought stress were accompanied by an increases in ranges (less uniform) for traits; days to $50 \%$ silking, days to $50 \%$ anthesis, days to $50 \%$ silking, anthesissilking interval.

Means of grain yield /plot of the highest $10 \mathrm{~S}_{1}$ progenies (selected on the basis of grain yield/plot) were 2.35 and $1.08 \mathrm{~kg} / \mathrm{plot}$ ) (with ranges from 2.05 to 2.61 and 1.01 to $1.18 \mathrm{~kg} / \mathrm{plot}$ ) under normal and drought stress conditions, respectively. The superiority of the $10 \mathrm{~S}_{1}$ 's over the $100 \mathrm{~S}_{1}$ 's in grain yield / plot was higher under drought stress $(57.59 \%)$ and normal conditions $(36.39 \%)$.Superiority of mean grain yield /plot of the $10 \mathrm{~S}_{1}$ 's over the $100 \mathrm{~S}_{1}$ 's was associated with superiority in number of kernels /row (11.01 and $16.31 \%)$ and days to $50 \%$ silking (-3.62 and $-3.81 \%$ ) under normal and drought stress conditions, respectively. On the other hand, the best $10 \mathrm{~S}_{1}$ 's in grain yield were characterized by lower means than the 100 $\mathrm{S}_{1}$ 's for days to $50 \%$ anthesis $(-2.48$ and $-1.97 \%)$, anthesis-silking interval (-37.73 and $-33.92 \%)$, Ear length (13.34 and 10.38\%), Ear diameter (9.49 and $3.48 \%$ ), number of rows /ear(12.42 and $7.36 \%$ ) and 100 -kernels weight (12.57 and $10.35 \%)$ under normal and drought stress conditions, respectively (Table 3 )

Table 2: Separate analysis of variance for all studied traits of $100 S_{1}$ 's (derived from Tep\#5) grown under normal (NI) and drought stress (DS) conditions.

\begin{tabular}{|c|c|c|c|c|c|c|c|c|c|c|}
\hline \multirow[b]{2}{*}{ S. O. V } & \multirow[b]{2}{*}{ d.f } & \multicolumn{9}{|c|}{ Mean squares } \\
\hline & & $\begin{array}{c}\text { Days to } \\
50 \% \\
\text { anthesis } \\
\text { (days) }\end{array}$ & $\begin{array}{c}\text { Days to } \\
\mathbf{5 0 \%} \\
\text { silking } \\
\text { (days) } \\
\end{array}$ & $\begin{array}{l}\text { Anthesis- } \\
\text { silking } \\
\text { interval } \\
\text { (days) }\end{array}$ & $\begin{array}{c}\text { Ear } \\
\text { length } \\
\text { (cm) }\end{array}$ & $\begin{array}{c}\text { Ear } \\
\text { diameter } \\
\text { (cm) }\end{array}$ & $\begin{array}{c}\text { Number } \\
\text { of rows / } \\
\text { ear }\end{array}$ & $\begin{array}{c}\text { Number } \\
\text { of kernels } \\
\text { / row }\end{array}$ & $\begin{array}{c}100- \\
\text { kernels } \\
\text { weight(g) }\end{array}$ & $\begin{array}{c}\text { Grain } \\
\text { yield } \\
\text { /plot(kg) }\end{array}$ \\
\hline & & \multicolumn{9}{|c|}{ Normal condition } \\
\hline Replications & 2 & 2.973 & 2.003 & 1.110 & 1.201 & 0.016 & 0.093 & 12.010 & 0.576 & 0.062 \\
\hline Genotypes & 99 & $11.626^{* *}$ & $16.402^{* *}$ & $2.663^{* *}$ & $4.730^{* *}$ & $0.164^{* *}$ & $3.320^{* *}$ & $12.743^{* *}$ & $13.961 * *$ & $0.165 * *$ \\
\hline Error & 198 & 3.354 & 3.646 & 1.134 & 1.729 & 0.071 & 1.467 & 5.616 & 5.589 & 0.034 \\
\hline \multirow[t]{2}{*}{ C.V.\% } & & 3.361 & 3.391 & 58.500 & 7.416 & 6.688 & 9.284 & 6.984 & 8.304 & 10.677 \\
\hline & & \multicolumn{9}{|c|}{ Drought stress } \\
\hline Replications & 2 & 4.120 & 3.270 & 0.070 & 2.323 & 0.080 & 0.520 & 2.582 & 0.666 & 0.021 \\
\hline Genotypes & 99 & $6.099^{* *}$ & $9.897^{* *}$ & $2.002^{* *}$ & $5.074^{* *}$ & $0.157^{* *}$ & $3.214^{* *}$ & $27.790^{* *}$ & $16.040^{* *}$ & $0.131^{* *}$ \\
\hline Error & 198 & 1.585 & 1.519 & 0.309 & 0.807 & 0.060 & 0.951 & 2.926 & 1.896 & 0.009 \\
\hline C.V.\% & & 2.240 & 2.067 & 16.208 & 6.142 & 6.216 & 7.478 & 6.276 & 5.237 & 13.772 \\
\hline
\end{tabular}

** indicate significance at 0.01 level of probability. 
Table 3: Means and ranges for all studied traits of $100 S_{1}$ 's and selected $10 S_{1}$ 's (based on grains yield / plot) derived from Tep\#5 population evaluated under normal (NI) and drought stress (DS) conditions.

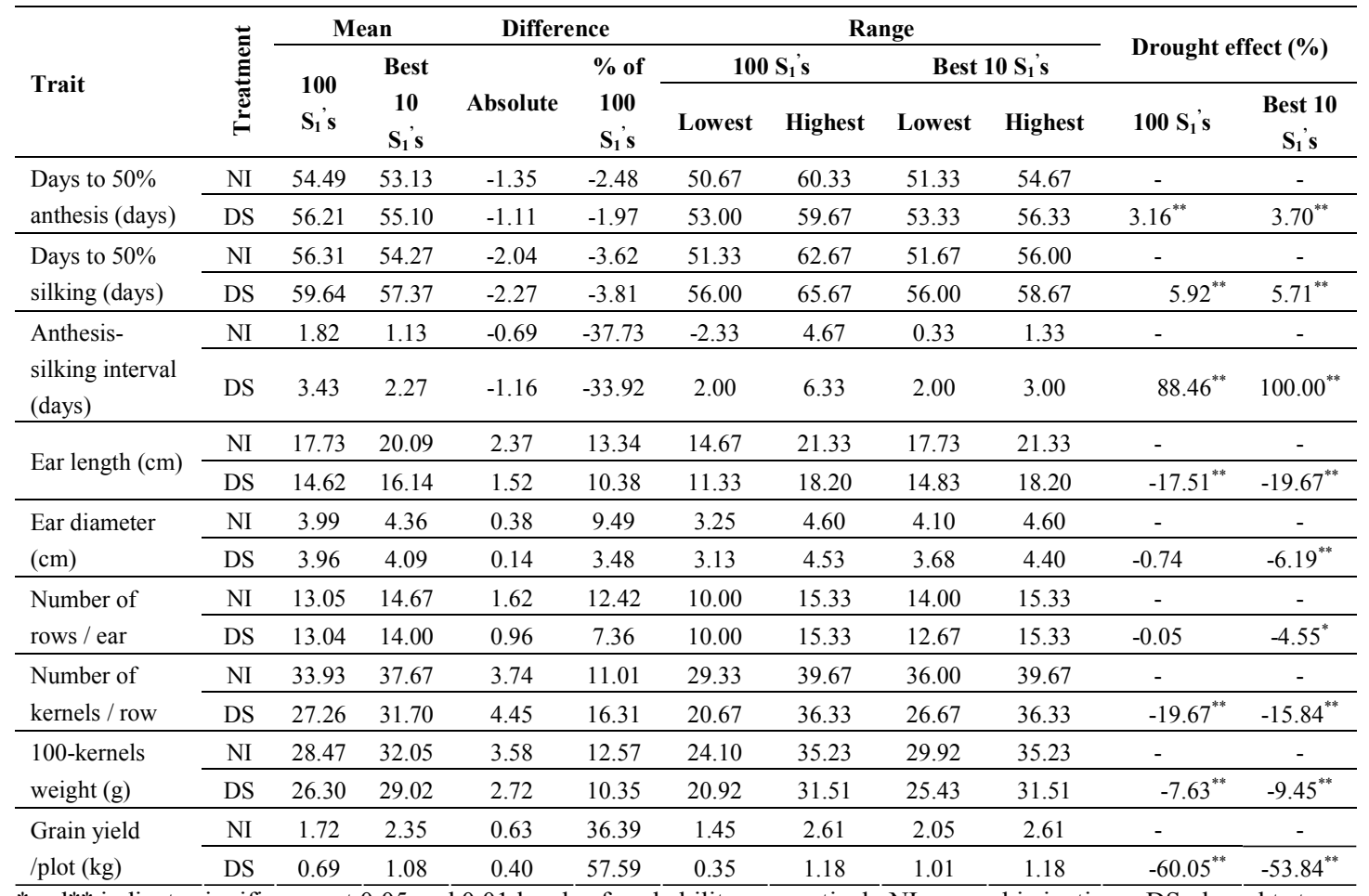

*and** indicate significance at $\overline{0.05 \text { and } 0.01 \text { levels of probability, respectively.NI; normal irrigation - DS; drought stress }} \overline{\frac{1}{0.01}}$

Significant reduction of $53.84 \%$ in grain yield /plot of the best $10 \mathrm{~S}_{1}$ 's due to drought stress was accompanied by reductions in number of rows /ear (4.55\%), number of kernels /row (15.84\%), 100-kernels weight (9.45\%), ear diameter $(6.19 \%)$ and ear length (19.67), i.e.; in all yield components. However, reductions due to drought stress were lower for the selected $10 \mathrm{~S}_{1}$ 's than those of the $100 \mathrm{~S}_{1}$ 's for all studied traits, except, days to $50 \%$ silking, days to $50 \%$ anthesis, anthesis-silking interval, where reduction due to drought stress were higher. Similar results were obtained by Magorokosho et al. (2003); Moser (2004); Shaboon (2004) and Hussein et al. (2019).

\section{c. Variance components and heritability}

Changes in the magnitude of genotypic $\left(\sigma_{\mathrm{g}}^{2}\right)$ and phenotypic $\left(\sigma_{\mathrm{p}}^{2}\right)$ variances, as well as the estimated corresponding broad-sense heritability $\left(\mathrm{h}^{2}{ }_{\mathrm{b}}\right)$ of the studied traits of the $100 \mathrm{~S}_{1}$ progenies from normal to drought stress experiments were presented in (Table 4). The changes in magnitude of $\sigma_{p}^{2}$ from normal to drought stressed environment was in the same direction for days to $50 \%$ anthesis, days to $50 \%$ silking, anthesis-silking in terval, ear diameter, number of rows/ear and grain yield/plot traits, where, the magnitude of $\sigma_{p}^{2}$ was smaller under drought stressed than normal environment. On the other hand, the magnitude of $\sigma_{p}^{2}$ was larger under drought stress than normal environment for number of kernels/row, 100-kernels weight and ear length traits. While, the $\sigma_{\mathrm{g}}^{2}$ values of anthesis-silking interval, ear length, ear diameter, number of kernels/row, 100-kernels weight, number of rows/ear and grain yield/plot traits, were higher under drought stress than normal irrigation. On the other hand, the magnitude of $\sigma_{\mathrm{g}}^{2}$ was smaller under drought stressed than normal environment for days to $50 \%$ anthesis and days to $50 \%$ silking traits. This might indicate that, selection under drought stress is successful than normal conditions. Similar results were obtained by Cairns et al. (2013) and Al-Naggar et al. (2009).

Heritability for grain yield/plot showed a general magnitude of increase with imposing drought stress (79.54\% under the normal to $93.17 \%$ under drought stress environments) (Table 8). Moreover, for all studied yield components, including number of rows/ear, number of kernels/row and 100-kernels, weight the magnitude of $\mathrm{h}^{2}{ }_{\mathrm{b}}$ was larger under drought stress than normal conditions. Broad-sense heritability $\left(\mathrm{h}_{\mathrm{b}}^{2}\right)$ estimates were generally of medium magnitude for all studied traits under normal conditions, except grains yield/plot, days to $50 \%$ silking and days to $50 \%$ anthesis that showed high magnitud. This might due to the magnitude of genotypic variance $\left(\sigma_{\mathrm{g}}^{2}\right)$ for these characters $(2.5$ times the environmental variance $\left.\left(\sigma_{\mathrm{e}}^{2}\right)\right)$. 
Table 4: Genetic $\left(\sigma_{, g}^{2}\right)$ and phenotypic $\left(\sigma_{p}^{2}\right)$ variances, and heritability in the broad sense $\left(h_{b}^{2}\right)$ for all studied traits of $100 \mathrm{~S}_{1} \mathrm{~s}$ (derived from Tep\#5 population) evaluated under normal (NI)and drought stress (DS) conditions.

\begin{tabular}{|c|c|c|c|c|c|c|c|c|c|c|}
\hline \multirow{3}{*}{$\begin{array}{l}\text { Trait } \\
\text { Days to } 50 \% \text { anthesis }\end{array}$} & \multirow{2}{*}{\multicolumn{2}{|c|}{$\begin{array}{c}\sigma_{p}^{2} \quad C . V_{P} \\
\text { Normal } \\
\text { irrigation }\end{array}$}} & \multirow{2}{*}{\multicolumn{2}{|c|}{$\begin{array}{c}\sigma_{p}^{2} \quad C . V_{P} \\
\begin{array}{c}\text { Drought } \\
\text { stress }\end{array}\end{array}$}} & \multirow{2}{*}{\multicolumn{2}{|c|}{$\begin{array}{c}\sigma_{\mathrm{g}}^{2} \quad \mathrm{C} . \mathrm{V}_{\mathrm{g}} \\
\text { Normal } \\
\text { irrigation }\end{array}$}} & $\sigma_{g}^{2}$ & C.V $V_{g}$ & \multicolumn{2}{|c|}{$h_{b}^{2} \%$} \\
\hline & & & & & & & \multicolumn{2}{|c|}{$\begin{array}{c}\text { Drought } \\
\text { stress }\end{array}$} & \multirow{2}{*}{$\begin{array}{c}\begin{array}{c}\text { Normal } \\
\text { irrigation }\end{array} \\
71.15 \\
\end{array}$} & \multirow{2}{*}{$\begin{array}{c}\begin{array}{c}\text { Drought } \\
\text { stress }\end{array} \\
74.02 \\
\end{array}$} \\
\hline & 3.88 & 7.11 & 2.03 & 3.62 & 2.76 & 5.06 & 1.50 & 2.68 & & \\
\hline Days to $50 \%$ silking & 5.47 & 9.71 & 3.30 & 5.53 & 4.25 & 7.55 & 2.79 & 4.68 & 77.77 & 84.65 \\
\hline Anthesis-silking interval & 0.89 & 48.77 & 0.67 & 19.46 & 0.51 & 28.01 & 0.56 & 16.45 & 57.43 & 84.56 \\
\hline Ear length $(\mathrm{cm})$ & 1.58 & 8.89 & 1.69 & 11.57 & 1.00 & 5.64 & 1.42 & 9.73 & 63.45 & 84.10 \\
\hline Ear diameter $(\mathrm{cm})$ & 0.05 & 1.37 & 0.05 & 1.33 & 0.03 & 0.78 & 0.03 & 0.82 & 56.64 & 61.58 \\
\hline No. of rows / ear & 1.11 & 8.48 & 1.07 & 8.22 & 0.62 & 4.73 & 0.75 & 5.78 & 55.81 & 70.41 \\
\hline No. of kernels / row & 4.25 & 12.52 & 9.26 & 33.99 & 2.38 & 7.00 & 8.29 & 30.41 & 55.93 & 89.47 \\
\hline 100-kernels weight $(\mathrm{g})$ & 4.65 & 16.35 & 5.35 & 20.33 & 2.79 & 9.80 & 4.71 & 17.93 & 59.96 & 88.18 \\
\hline Grain yield / Plot $(\mathrm{kg})$ & 0.06 & 3.20 & 0.04 & 6.36 & 0.04 & 2.54 & 0.04 & 5.93 & 79.54 & 93.17 \\
\hline
\end{tabular}

C. $\mathrm{V}_{\mathrm{P} ;}$ phenotypic coefficient of variation - C. $\mathrm{V}_{\mathrm{g}}$; genotypic coefficient of variation

Broad-sense heritability $\left(\mathrm{h}_{\mathrm{b}}^{2}\right)$ estimates were very high for all studied traits under drought stress because the genotypic variance $\left(\sigma_{g}^{2}\right)$ for these characters was 2.5 times the environmental variance $\left(\sigma_{\mathrm{e}}^{2}\right)$, except ear diameter was medium magnitude. These results confirm with those reported by Beyene et al. (2015) and El-Rouby et al. (2017).

\section{a. Correlations between traits}

Under drought experiment, data in Table (5) indicated a significant positive genetic correlation between grain yield/plot and number of kernels/row $\left(r_{g}=0.47\right)$, ear diameter $\left(r_{g}=0.41\right)$, number of rows/ear $\left(r_{g}=0.27\right), 100$-kernels weight $\left(r_{g}=0.40\right)$ and ear length $\left(r_{g}=0.45\right)$. Results also showed a significant negative correlation between grain yield/plot and days to $50 \%$ silking $\left(\mathrm{r}_{\mathrm{g}}=-0.67\right)$, anthesis-silking interval $\left(\mathrm{r}_{\mathrm{g}}=-0.62\right)$ and days to $50 \%$ anthesis $\left(r_{\mathrm{g}}=-0.53\right)$ under drought stress conditions. These characters could be used for indirect selection for yield especially if they were less affected by environment. Under normal condition, grain yield/plot had a significant positive genetic association with ear length $\left(\mathrm{r}_{\mathrm{g}}=0.94\right)$, number of kernels /row $\left(r_{g}=0.82\right)$, row/ear $\left(r_{g}=\right.$ 0.81), 100-kernels weight $\left(r_{g}=0.69\right)$ and ear diameter $\left(r_{g}=0.66\right)$. On the other hand, a significant negative genetic associations was observed between grain yield/plot and anthesis-silking interval $\left(r_{g}=\right.$ $0.35)$, days to $50 \%$ silking $\left(\mathrm{r}_{\mathrm{g}}=-0.28\right)$ and days to $50 \%$ anthesis $\left(r_{\mathrm{g}}=-0.20\right)$ under normal conditions. These results are in agreement with those reported by Al-Naggar et al. (2009); Cairns et al. (2013) and El-Rouby et al. (2017).

Experiment II: Evaluation of the effectiveness of $S_{1}$ recurrent selection.

\section{a. Analysis of variance}

Mean squares for physiological and biochemical traits, yield and its components and kernels quality in the cycles $\left(\mathrm{C}_{0}\right.$ and $\left.\mathrm{C}_{1}\right)$ derived from Tep\#5 under normal and drought stress conditions are shown in tables $(6 \& 7 \& 8)$.

Table 5: Genetic correlations $\left(r_{\mathrm{g}}\right)$ between pairs of studied traits of the $100 \mathrm{~S}_{1}$ progenies (derived from Tep\#5 population) under normal (below diagonal) and drought stress (above diagonal) conditions.

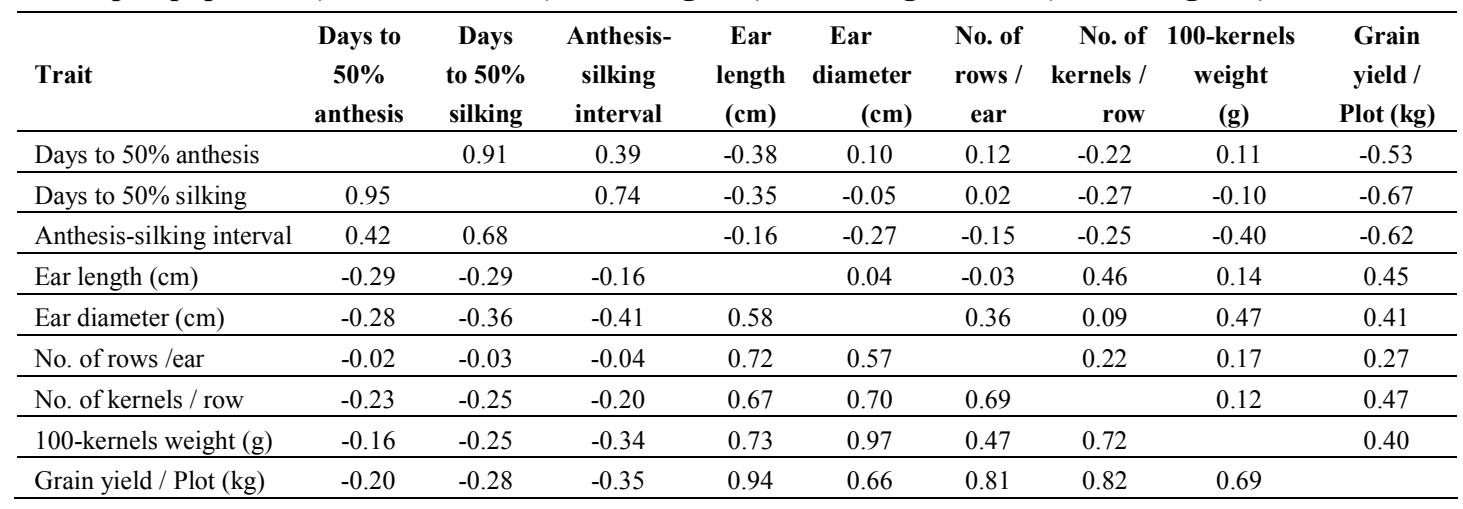


Table 6: Mean squares of physiological and biochemical traits for the $1^{\text {st }}$ cycle population (derived from Tep\#5) under normal and drought stress conditions.

\begin{tabular}{|c|c|c|c|c|c|c|c|c|}
\hline \multirow[t]{2}{*}{ S. O. V } & \multirow[t]{2}{*}{ d.f } & \multicolumn{7}{|c|}{ Mean squares } \\
\hline & & $\begin{array}{l}\text { Chlorophyll } \\
\text { (SPAD) }\end{array}$ & $\begin{array}{c}\text { Relative } \\
\text { water } \\
\text { content } \\
(\%)\end{array}$ & $\begin{array}{c}\text { Transpiration } \\
\text { rate } \\
\text { (mg/gfw.hr) }\end{array}$ & $\begin{array}{c}\text { Osmotic } \\
\text { pressure } \\
\text { C.S. } \\
\text { (bar) }\end{array}$ & $\begin{array}{l}\text { Peroxidase } \\
\text { activity } \\
\text { (O.D. /g } \\
\text { F.W.) }\end{array}$ & $\begin{array}{c}\text { Phenoloxidase } \\
\text { activity } \\
\text { (O.D. /g F.W.) }\end{array}$ & $\begin{array}{c}\text { Proline } \\
\text { content } \\
(\mu \mathrm{g} / \mathrm{g} \\
\text { D.W. })\end{array}$ \\
\hline & \multicolumn{8}{|c|}{ Normal conditions } \\
\hline Replications & 3 & 0.163 & 0.014 & 0.415 & 0.042 & 0.0001 & 0.0000 & 69.493 \\
\hline Genotypes & 1 & 7.220 & $3.143^{*}$ & 24.256 & 0.060 & 0.0006 & $0.0002^{*}$ & 131.166 \\
\hline Error & 3 & 1.305 & 0.108 & 3.517 & 0.023 & 0.0001 & 0.0000 & 244.035 \\
\hline \multirow[t]{2}{*}{ C.V.\% } & & 2.363 & 0.479 & 5.921 & 0.582 & 1.294 & 2.506 & 2.257 \\
\hline & & \multicolumn{7}{|c|}{ Drought stress } \\
\hline Replications & 3 & 0.091 & 0.128 & 0.087 & 0.232 & 0.0000 & 0.0000 & 206.713 \\
\hline Genotypes & 1 & $22.819^{* *}$ & $30.254^{* *}$ & $36.642^{* *}$ & $3.712^{* *}$ & $0.0011^{* *}$ & $0.0006^{*}$ & $3663.965^{* *}$ \\
\hline Error & 3 & 0.269 & 0.329 & 0.507 & 0.0398 & 0.0000 & 0.0000 & 48.842 \\
\hline C.V.\% & & 1.259 & 0.927 & 2.562 & 0.745 & 0.690 & 3.476 & 0.885 \\
\hline
\end{tabular}

Table 7: Mean squares of yield and its components for the $1^{\text {st }}$ cycle population (derived from Tep\#5) under normal and drought stress conditions.

\begin{tabular}{|c|c|c|c|c|c|c|c|c|c|c|c|}
\hline \multirow[t]{2}{*}{ S. O. V } & \multirow[t]{2}{*}{ d.f } & \multicolumn{10}{|c|}{ Mean squares } \\
\hline & & $\begin{array}{c}\text { Plant } \\
\text { height }(\mathrm{cm})\end{array}$ & $\begin{array}{c}\text { Ear } \\
\text { height } \\
(\mathrm{cm})\end{array}$ & $\begin{array}{c}\text { Ear } \\
\text { length } \\
(\mathrm{cm})\end{array}$ & $\begin{array}{c}\text { Ear } \\
\text { diameter } \\
(\mathrm{cm})\end{array}$ & $\begin{array}{l}\text { No. of } \\
\text { ears / } \\
\text { plant }\end{array}$ & $\begin{array}{c}\text { No. of } \\
\text { rows / } \\
\text { ear }\end{array}$ & $\begin{array}{c}\text { No. of } \\
\text { kernels / } \\
\text { row }\end{array}$ & $\begin{array}{c}100- \\
\text { kernels } \\
\text { weight (g) }\end{array}$ & $\begin{array}{l}\text { Weight } \\
\text { kernels } \\
\text { /ear (g) } \\
\end{array}$ & $\begin{array}{c}\text { Grain } \\
\text { yield } \\
\text { (ton/fad) }\end{array}$ \\
\hline & & \multicolumn{10}{|c|}{ Normal conditions } \\
\hline Replications & 3 & 52.333 & 52.778 & 0.031 & 0.011 & 0.000 & 0.004 & 0.071 & 0.066 & 5.919 & 0.001 \\
\hline Genotypes & 1 & $2403.56^{* *}$ & $1058.0^{*}$ & 0.014 & 0.027 & 0.006 & 0.080 & $21.342 * *$ & $2.682 * *$ & $935.31^{*}$ & $0.242 * *$ \\
\hline Error & 3 & 22.111 & 46.333 & 0.004 & 0.015 & 0.001 & 0.040 & 0.551 & 0.069 & 14.963 & 0.005 \\
\hline \multirow[t]{2}{*}{ C.V.\% } & & 2.515 & 6.598 & 0.372 & 2.667 & 2.842 & 1.367 & 2.008 & 0.938 & 2.555 & 2.407 \\
\hline & \multicolumn{11}{|c|}{ Drought stress } \\
\hline Replications & 3 & 13.444 & 0.778 & 0.076 & 0.018 & 0.001 & 0.033 & 0.034 & 0.304 & 6.802 & 0.002 \\
\hline Genotypes & 1 & $410.889^{*}$ & $56.889 *$ & 0.161 & 0.036 & $0.035 * *$ & 0.109 & $15.309^{* *}$ & $11.985 * *$ & $857.36^{*}$ & $0.164 * *$ \\
\hline Error & 3 & 18.778 & 4.111 & 0.076 & 0.018 & 0.001 & 0.033 & 0.301 & 0.279 & 1.996 & 0.004 \\
\hline C.V.\% & & 2.835 & 2.188 & 1.790 & 3.279 & 2.967 & 1.331 & 1.855 & 2.093 & 1.385 & 3.249 \\
\hline
\end{tabular}

Table 8: Mean squares of kernels quality for the $1^{\text {st }}$ cycle population (derived from Tep\#5) under normal and drought stress conditions.

\begin{tabular}{|c|c|c|c|}
\hline \multirow{2}{*}{ S. O. V } & \multirow{2}{*}{ d.f } & \multicolumn{2}{|c|}{ Mean squares } \\
\hline & & Crude protein in kernels $(\%)$ & Protein yield (kg/fad) \\
\hline & & \multicolumn{2}{|c|}{ Normal conditions } \\
\hline Replications & 3 & 0.055 & 74.907 \\
\hline Genotypes & 1 & $1.411^{*}$ & $6237.987 * *$ \\
\hline Error & 3 & 0.066 & 48.381 \\
\hline \multirow[t]{2}{*}{ C.V.\% } & & 2.906 & 2.626 \\
\hline & & \multicolumn{2}{|c|}{ Drought stress } \\
\hline Replications & 3 & 0.112 & 41.425 \\
\hline Genotypes & 1 & $0.334^{*}$ & $1899.274 * *$ \\
\hline Error & 3 & 0.025 & 36.459 \\
\hline C.V.\% & & 1.969 & 3.833 \\
\hline
\end{tabular}

*and** indicate significance at 0.05 and 0.01 levels of probability, respectively. 
Analysis of variance insignificant differences between Tep\#5 and Tep\#5-NI populations under normal conditions for all studied traits, except for, relative water content, Phenoloxidase activity, plant height, ear height, number of kernels / row, 100kernels weight, weight kernels /ear, grain yield, crude protein in kernels and protein yield; while, a significant differences between Tep\#5 and Tep\#5DS populations under drought stress conditions were noticed for all studied traits, except for, ear length, ear diameter and number of rows / ear.

\section{b. Performance of populations}

Mean of physiological and biochemical traits, yield and its components and kernels quality in the new cycle derived from Tep\#5 under different environments (normal and drought stress) during 2018 season are presented in Tables ( 9 \& 10 \& 11).

\section{Physiological and biochemical traits}

Results in Table 9 indicated that, drought stress causes a reduction in chlorophyll, relative water content, transpiration rate, peroxidase activity and phenoloxidase activity, while it causes increase in osmotic pressure and proline content in leaves compared to normal conditions.

Under normal condition, superiority of $\mathrm{C}_{1}$ population (Tep\#5-NI) over the original population (Tep\#5) in relative water content and phenoloxidase activity. The rate of increase in $\mathrm{C}_{1}$ relative to $\mathrm{C}_{0}$ for relative water content and phenoloxidase activity were amounted to $1.84 \%$ and $6.25 \%$, respectively. Meanwhile, under drought stress conditions, the superiority of $\mathrm{C}_{1}$ population (Tep\#5-DS) over the original population (Tep\#5) was existed for all studied traits. The rate of increase in $\mathrm{C}_{1}$ (tep\#5-NI) relative to $\mathrm{C}_{0}($ tep\#5) for chlorophyll, relative water content, osmotic pressure, peroxidase activity, phenoloxidase activity and proline content were amounted to8.56, 6.49, 5.25, 5, 6.67 and 5.57\% respectively. However, the rate of decrease for transpiration rate was $14.30 \%$. Water stress could restrict internode elongation and leaf expansion through inhibiting cell expansion (Namich, 2007). Relative water content has been reported as an

Table 9: Mean performance of physiological traits for the $1^{\text {st }}$ cycle population (derived from Tep\#5) under normal and drought stress conditions.

\begin{tabular}{|c|c|c|c|c|c|c|c|c|}
\hline \multirow{2}{*}{\multicolumn{2}{|c|}{ Populations }} & \multicolumn{7}{|c|}{ Mean } \\
\hline & & \multirow[t]{2}{*}{ chlorophyll } & \multirow[t]{2}{*}{$\begin{array}{c}\text { Relative } \\
\text { water } \\
\text { content } \\
(\%)\end{array}$} & $\begin{array}{c}\text { Transpiration } \\
\text { rate } \\
\text { (mg/gfw.h) }\end{array}$ & $\begin{array}{c}\text { Osmotic } \\
\text { pressure } \\
\text { C.S. } \\
\text { (bar) } \\
\end{array}$ & \multirow[t]{2}{*}{$\begin{array}{c}\text { Peroxidase } \\
\text { activity } \\
\text { (O.D./g } \\
\text { F.W.) } \\
\end{array}$} & \multirow[t]{2}{*}{$\begin{array}{c}\text { Phenoloxidase } \\
\text { activity } \\
\text { (O.D. /g F.W.) }\end{array}$} & \multirow[t]{2}{*}{$\begin{array}{r}\text { Proline } \\
\text { content } \\
(\mu \mathrm{g} / \mathrm{g} \\
\text { D.W. })\end{array}$} \\
\hline & & & & Normal c & nditions & & & \\
\hline \multirow{2}{*}{ Tep\#5 } & Original & 47.40 & 67.92 & 33.41 & 25.98 & 0.71 & 0.16 & 688.10 \\
\hline & $\mathrm{C}_{1}$ & 49.30 & 69.17 & 29.93 & 25.80 & 0.72 & 0.17 & 696.20 \\
\hline \multirow[t]{2}{*}{ L.S.D } & 0.05 & 2.570 & 0.739 & 4.220 & 0.339 & 0.021 & 0.009 & 35.153 \\
\hline & \multicolumn{8}{|c|}{ Drought stress } \\
\hline \multirow{2}{*}{ Tep\#5 } & Original & 39.50 & 59.97 & 29.93 & 26.10 & 0.60 & 0.15 & 768.16 \\
\hline & $\mathrm{C}_{1}$ & 42.88 & 63.86 & 25.65 & 27.47 & 0.63 & 0.16 & 810.96 \\
\hline L.S.D & 0.05 & 1.167 & 1.291 & 1.602 & 0.449 & 0.010 & 0.012 & 15.727 \\
\hline
\end{tabular}

important indicator of water stress in leaves, which is directly related to soil water content. Osmotic adjustment is an active accumulation of solutes within the plant in response to decrease in soil water potential, thus reducing the harmful effects of water deficit. Under stressed conditions, cell membranes are subject to changes often associated with the increase in the cell permeability. These results are in consistence to those reported by Efeoglu et al. (2009); Heidari and Moaveni (2009); Hammad and Ali (2014) and Gomaa et al. (2017).

\section{Yield and its components}

Data in Table 10 indicated that, drought stress condition affected grain yield and its components, where, grain yield was reduce from 2.81 ton/fad under normal condition to $1.81 \mathrm{ton} / \mathrm{fad}$ under drought stress for $\mathrm{C}_{0}$ (decrease rate $35.59 \%$ ). $\mathrm{C}_{1}$ yield was reduce from 3.16 ton/fad under normal condition to 2.09 ton/fad under drought stress by $(33.86 \%)$

Under normal condition, a superiority of $\mathrm{C}_{1}$ population (Tep\#5-NI) over the original population (Tep\#5) in plant height, ear height, number of kernels /row, 100-kernels weight, weight kernels /ear and grain yield traits amounted to 20.43, 25.09, 2.26, $4.22,15.38$ and $12.46 \%$, respectively. Meanwhile, under drought stress conditions, the superiority of $\mathrm{C}_{1}$ population (Tep\#5 DS) over the original population (Tep\#5) existed for all studied traits, except, ear length, ear diameter and number of rows /ear traits.

The rate of increase in $C_{1}$ (tep\#5-DS) relative to $C_{0}$ (tep\#5) for plant height, ear height, number of ears /plant, number of kernels /row, 100-kernels weight, weight kernels /ear and grain yield amounted to 9.84, 5.92, 18.67, 9.82, 10.20, 22.59 and $15.47 \%$, respectively. The two improved populations showed significant superiority in grain yield/fad over original population under normal and drought stress conditions. These results are in agreement with those reported by Singh et al. (2000); Gamea (2010); Sadalla et al. (2014) and Beyene et al. (2015). 
Table 10: Mean performance of yield and its components for the $1^{\text {st }}$ cycle population (derived from Tep\#5) under normal and drought stress conditions.

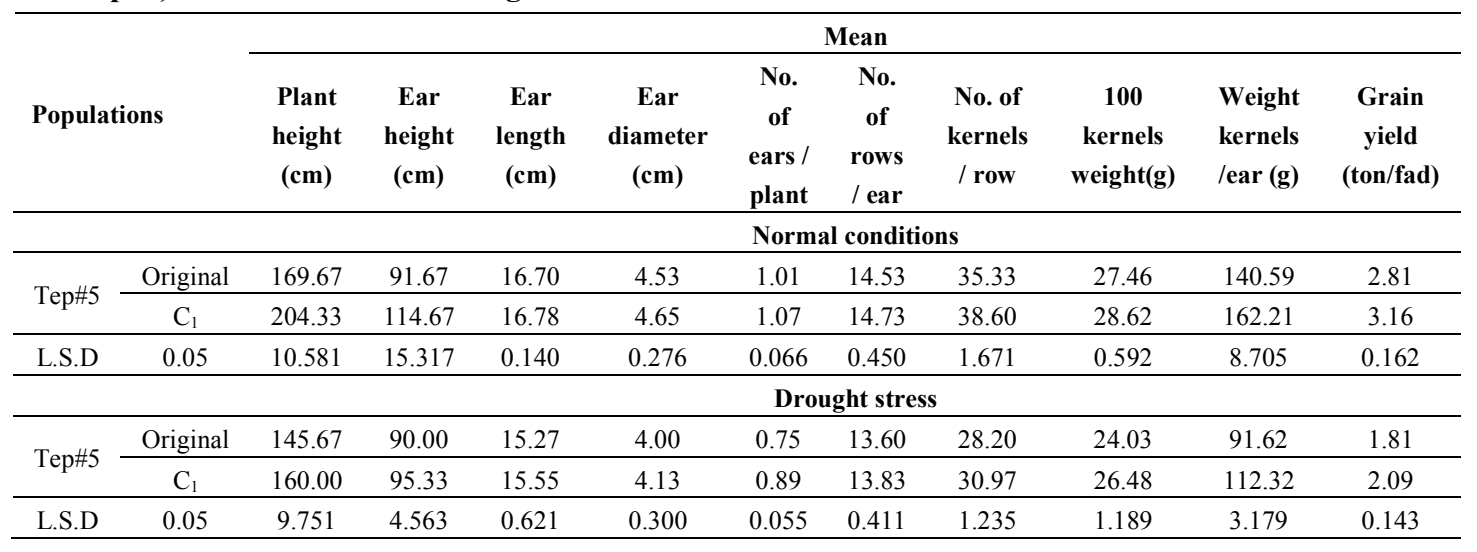

Table 11: Mean performance of kernels quality for the $1^{\text {st }}$ cycle population (derived from Tep\#5) under normal and drought stress conditions.

\begin{tabular}{|c|c|c|c|}
\hline \multirow{2}{*}{ Populations } & & \multicolumn{2}{|c|}{ Mean } \\
\hline & & Crude protein in kernels (\%) & Protein yield $(\mathrm{kg} / \mathrm{fad})$ \\
\hline & & \multicolumn{2}{|c|}{ Normal conditions } \\
\hline \multirow{2}{*}{ Tep\#5 } & Original & 8.43 & 236.95 \\
\hline & $\mathrm{C}_{1}$ & 9.27 & 292.80 \\
\hline \multirow[t]{2}{*}{ L.S.D } & 0.05 & 0.579 & 15.652 \\
\hline & & \multicolumn{2}{|c|}{ Drought stress } \\
\hline \multirow{2}{*}{ Tep\#5 } & Original & 7.86 & 142.11 \\
\hline & $\mathrm{C}_{1}$ & 8.27 & 172.93 \\
\hline L.S.D & 0.05 & 0.357 & 13.587 \\
\hline
\end{tabular}

\section{Kernels quality}

Results in Table 11 indicated that, drought stress causes a reduction in kernels crude protein and protein yield. The $\mathrm{C}_{1}$ population (Tep\#5-NI and Tep\#5-DS) showed superiority in kernels quality traits over the original population (Tep\#5) under normal and drought stress environments, respectively. These results are in agreement with those reported by Okporie et al. (2013).

\section{REFERENCES}

AACC (2000). American Association of Cereal Chemists. Approved Methods of the AACC, $10^{\text {th }}$ ed. St. Paul. Minnesota, USA.

Al-Naggar, A.M.M.; R. Shabana; A.A. Mahmoud; M.E.M. Abd El-Azeem and S.A.M. Shaboon (2009). Recurrent selection for drought tolerance improves maize productivity under low-N conditions. Egypt. J. Plant Breed. Vol. 13: $53-70$.

Al-Naggar, A.M.M.; R. Shabana; S.E. Sadek and S.A.M. Shaboon (2004). $S_{1}$ recurrent selection for drought tolerance in maize. Egypt. J. Plant Breed. Vol. 8: 201-225

Barrs, H.D. and P.E. Weatherly (1962). Arc examination of the relative turgidity technique for estimating water deficits in leaves. Aust. J. BioI. Sci., Vol. 15: 413-428.
Bates, L.S.; R.P. Waldem and I.D. Teare (1973). Rapid determination of free proline under water-stress studies. Plant and Soil, Vol. 39: 205-207.

Betran, F.G. (1999). Applied quantitative genetics in plant breeding. Unpublished class notes. Texas, A \& M University Texas, USA.

Beyene, Y.; K. Semagn; S. Mugo; D. Makumbi; J. Gakunga; M. Olsen; B.M. Prasanna; A. Tarekegne; C. Magorokosho; R. Babu; B. Meisel; P. Sehabiague; S. Oikeh; M. Vargas; M. Banziger and J. Crossa (2015). Genetic gains in grain yield through genomic selection in eight bi-parental maize populations under drought stress. Crop Sci. Vol. 55: 154-163.

Black, C.A. (1982). Method of Soil Analysis. Soc. Agron. Inc. Pub., Madison, Washington, U.S.A. No. 9. Part 2.

Cairns, J. E.; J. Crossa; P.H. Zaidi; P. Grudloyma; C. Sanchez; J.L. Araus; S. Thaitad; D. Makumbi; C. Magorokosho; M. Bänziger; A. Menkir; S. Hearne and G.N. Atlin (2013). Identification of drought, heat, and combined drought and heat tolerant donors in maize (Zea mays L.). Crop Sci.; doi: 10.2135/cropsci.09.0545.

Chaves, M.M.; J.P. Maroco and J.S. Pereira (2003). Understanding plant responses to drought-from genes to the whole plant. Functional Plant Biology, Vol. 30: 239-264. 
Doerksen, T.K.; L.W. Kannenberg and E.A. Lee (2003). Effect of recurrent selection on combining ability in maize breeding populations. Crop Sci. Vol. 43: 1652-1658.

Efeoglu, B.; Y. Ekmekci and N. Cicek (2009). Physiological responses of three maize cultivars to drought stress and recovery. South Africa J. of Botany Vol. 75: 34-42.

El-Rouby, M.M.; M.H. El-Sheikh and Shimaa M. Awad Allah (2017). Increasing the Efficiency of Recurrent Selection for Yield in Maize. Alexandria Science Exchange J., Vol. 38 No. (2): 193-202.

FAOSTAT (2017). Food and Agriculture Organization of the United Nations (FAO) Statistical Databases.

Gamea, H.A.A. (2010). Genetic improvement of yield and oil percentage in maize. Ph.D. Thesis, Fac. Of Agric., Menoufia Univ., Egypt.

Gomaa, M.A.; I.F. Rehab; F.A. Salama and A.S.M. AL-Deeb (2017). Water-Stress in Relation to Maize (Zea mays L.) Grain Yield, Plant Height and Proline Content. Alex. J. Agric. Sci. Vol. 62 No. (3): $311 \square 317$.

Gosev, N.A. (1960). Some methods in studying plant water relation. Leningrad Acad. of Sc. U.S.S.R.

Hallauer, A.R. and J.B. Miranda (1988). Quantitative Genetics in Maize Breeding $2^{\text {nd }}$ edition. Iowa State Univ. press, Ames., IA., USA.

Hammad, Salwa A. and O.A.M. Ali (2014). Physiological and biochemical studies on drought tolerance of wheat plants by application of amino acids and yeast extract. Annals of Agric. Sci. Vol. 59 No. (1): 133145.

Heidari, Y. and P. Moaveni (2009). Study of drought stress on ABA accumulation and proline among in different genotypes forage corn. Research J. of Biological Sci. Vol. 4 No. (10): 1121-1124

Hussein, A.A.; N.M. El-Bialee and Ilham I. ElKhatib (2019). Response of Maize Crop to Water Deficit and Organic Fertilizers. J. Soil Sci. and Agric. Eng., Mansoura Univ., Vol. 10 No. (2): 107-113.

Jackson, M.L. (1973). Soil Chemical Analysis. Prentice Hall of India, Ltd., New Delhi, India.

Kreeb, K. H. (1990). MethodenzurPflanzenökologie und Bioindikation. Gustav Ficher, Jena, 327 pp.

Leta, T. and H. Jifar (2010). Advances in Improving Ukiriguru Composite B Maize (Zea mays L.) Variety through $S_{1}$ Recurrent Selection. East African J. of Sci. Vol. 4 No. (2): 78-85.
Maazou A.S.; T. U. Jialu; J. U. Qiu and Liu Zhizhai (2016). Breeding for Drought Tolerance in Maize (Zea mays L.). American J. of Plant Sci., 7: 1858-1870.

Magorokosho, C.; K.V. Pixley and P. Tongoona (2003). Selection for drought tolerance in two tropical maize populations. African J. Crop Sci., J., Vol. 11 No. (3): 151-161.

Matta, A. and A.E. Dimond (1963). Symptoms of fusarium within relation to quantity of fungus and enzyme activity in tomato stems. Phytopathol., Vol. 53: 574-578.

Moser, S. B. (2004). Effects of pre-anthesis drought stress and nitrogen on yield; nitrogen use efficiency; and grain minerals of tropical maize varieties. Ph. D. Thesis. Dipl. Ing. Agr. ETH Zurich, 227, pp.

Okporie, E.O.; S.C. Chukwu and G.C. Onyishi (2013). Phenotypic Recurrent Selection for Increase Yield and Chemical Constituents of Maize (Zea mays L.). World Appl. Sci. J., Vol. 21 No. (7): 994-999.

Rekaby, S.A.;M.A. Eissa; S.A. Hegab and H.M. Ragheb (2017). Effect of Water Stress on Maize Grown under Drip Irrigation System. Assiut J. Agric. Sci., (48) No. (1-1): 331-346.

Reuveni, R.; M. Shimoni; Z. Karchi and J. Kuc (1992). Peroxidase activity as a biochemical marker for resistance of muskmelon (Cucumismelo, L.) to Pseudoperonosporacubensis. Phytopathology, Vol. 82: 749-753.

Sadalla, H.A.; S.A. Kakarash and N.R. Mustafa (2014). Recurrent Selection and Half-Sib Selection for Improvement oil contained in Maize (Zea mays L.) Variety TALAR.J. Tikrit Univ. For Agri. Sci. Vol. 14 No. (2): ISSN1813-1646.

Shaboon, A.M.S. (2004). Genetic improvement via selection in maize. M. Sc. Thesis, Fac. Agric., Cairo Univ., Egypt, 176 pp.

Singh, R.D.; T.P. Yadav and J.S. Bhat (2000). Breeding strategies for drought tolerance in maize. J. of Crop Improvement, Vol. 27 No. (2): 167-177.

Snedecor, G. W. and W. G. Cochran (1989). Statistical Methods. $8^{\text {th }}$ Ed.; Iowa State Univ. Press, Ames, Iowa, USA.

Umar, U.U.; S.G. Ado; D.A. Aba and S.M. Bugaje (2015). Studies on genetic variability in maize (Zea mays L.) under stress and non-stress environmental conditions. IJAAR Vol. 7 No. (1): 70-77.

Wang W.; B. Vinocur and A. Altman (2003). Plant responses to drought, salinity and extreme temperatures: towards genetic engineering for stress tolerance. Planta; 218: 1-14. 


\section{الملخص العربي}

\section{تحسين تحمل الجفاف في عشيرة بيضاء الحبوب من الذرة الثامية}

شعبان أحمد الثمارقة'، إبراهيم حسيني درويش'، مروة محمد النحاس'، حمدي السيد جامع'،

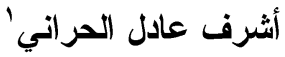

'قسم المحاصيل - كلية الزر اعة - جامعة المنوفية

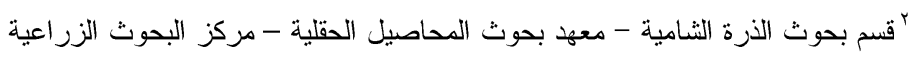

أجريت تجربة حقلية بالمزرعة البحثية بكلية الزر اعة جامعة المنوفية بشبين الكوم بمصر في أربعة مواسم

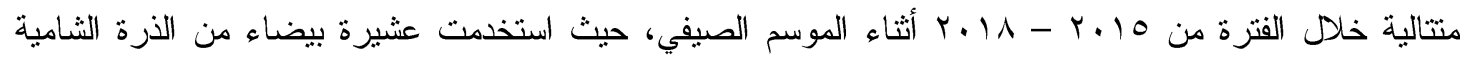

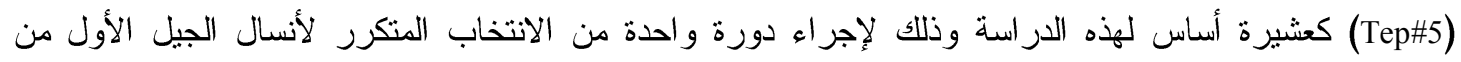

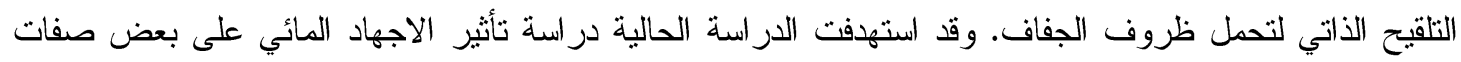
الذرة الثامية وتحديد أكثر الصفات المرتبطة بالإجهاد المائي مع المحصول لاستخدامها كمعيار انتخابي وكذلك تقدير كفاءة طريقة الانتخاب المتكرر لتحسين تحمل الإجهاد المائي في واحده من عشائر الذرة الثنامية البيضاء. تم تكوين

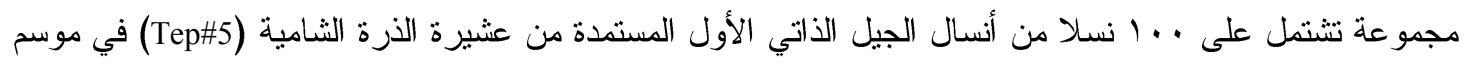

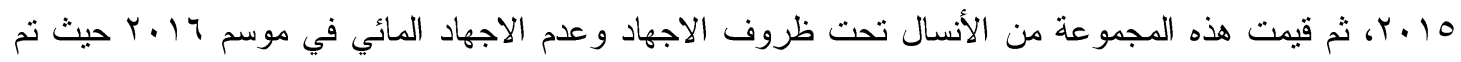

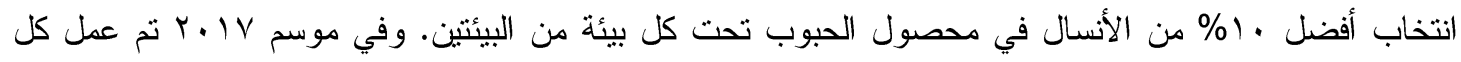

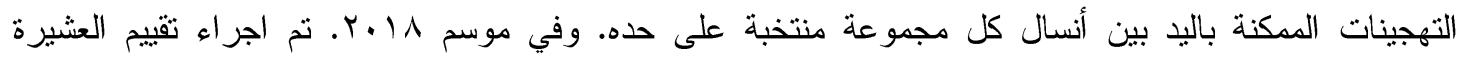

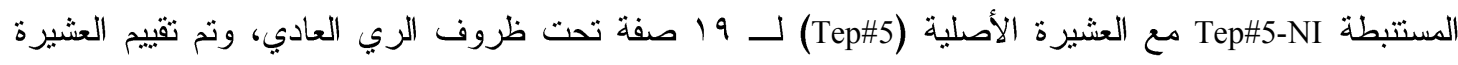
المستتبطة Tep\#5-DS مع العشيرة الأصلية تحت ظروف الاجهاد المائي، ونفذت كل تجربة على هيئة قطاعات كاملة

$$
\text { العشو ائية في أربعة مكررات. }
$$

أثنارت النتائج إلى وجود تباعد وراثي كبير بين أنسال الجيل الذاتي الأول لمعظم الصفات المدروسة تحت كل

من نظامي الري. كانت قيم معامل التوريث بمعناها العام أعلى بصفة عامة تحت ظروف ولت الاجهاد المائي عنها تحت

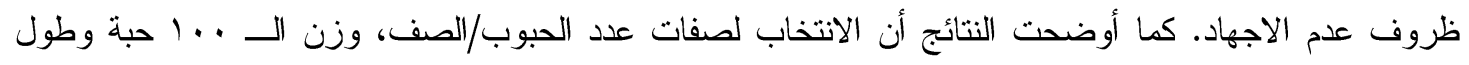
الكوز من المتوقع أن يكون أكثر فاعلية تحت ظروف الجفاف عنه تحت ظروف الري الكامل. أدت دورة واحدة من الانتخاب الدوري لأنسال الجيل الذاتي الأول لصفة محصول الحبوب تحت ظروف الحت الاجهاد المائي كبيئة انتخابية إلى دونى

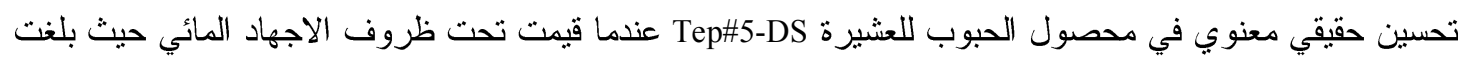
الزيادة V_0, 10 عن العشيرة الأصلية Tep\#5. كما أدت أيضاً دورة واحدة من الانتخاب الدوري لأنسال الجيل الذاتي الأول لصفة محصول الحبوب تحت ظروف الري الطبيعي كييئة انتخابية إلى تحسين حقيقي معنوي في

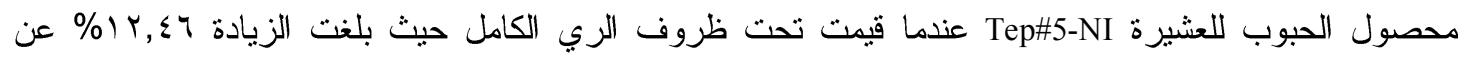
العثيرة الأصلية Tep\#5. اوضحت النتائج أمكانية استخدام طريقة الانتخاب الدوري Sأحد الوسائل البسيطة

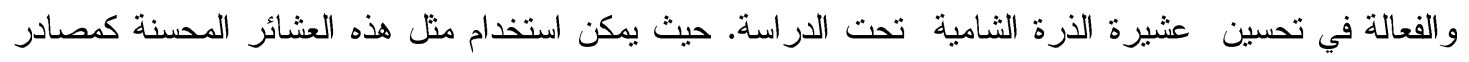
مناسبة لعزل سلالات جديدة تدخل في انتاج الهجن المتحملة للجفاف. 